\title{
Risk and Its Concept: Scientific and Artistic
}

Dear readers,

the term "risk" is one of the most frequently used concepts in economic science. The origin of this word is necessary to looking in ancient Greek, where the word "riza" (written " $\rho 1 \zeta \alpha$ ") supposedly signified the "root" i.e. a kind of obstacle in the way of which a wayfarer could trip up on his road. In a similar meaning the term later appeared in Latin, which represented a "cliff" on which can ships may break. Then the word began occur in similar form in the other languages in the sense of danger, which traders have to face during transport by the sea. The word "risk" probably entered English through continental Europe to the $17^{\text {th }}$ century. From there, we are close to understanding risk as any danger, whether at work, in politics, in trade, in finance, in life or even in love.

In terms of theoretical discussions on the concept of risk the following five questions, which are still the subject of scholarly debate, can be observed. Does the risk represent same concept as the uncertainty? Can we define the risk as probability? Does the risk measurable and the uncertainty immeasurable? Does the risk constituted only by negative deviations from the expected results or also by positive? Does a risk exist without uncertainty?

In advance it must be noted that although there may be varied approaches to the definition of a risk, eventually all the authors may be right. In terms of factual logic, each definition would apply only under certain conditions. And in this sense, each author could work with different conditions, whether expressly mentioned or not. Thus it could not be unequivocally said which answer to the questions above is the only right one, since each author has the right to choose his/her own path. To summarize the previous approaches, then the term risk usually means the threat of an event e.g. a trip up protruding root, shipwreck on the reef, or financial losses from unrealized sales, goods damage, failure to pay for 
delivery, etc. In other words, the risk is "danger that actual results will differ from expected results" 1 .

The concept of the risk is not a concept to which the science would have the exclusive right to explain. Different approaches to understand its nature can be found in the art world. The risk became the subject of many songs, poems, but also artistic, literary or dramatic works.

If we look at the lyrics of the songs titled "Risk", the closest to the scientific definition is country music singer Paul Brandt who compares the risk to a situation of standing on the edge of a cliff, by which he actually gets to the original meaning of the word in ancient Greek. ${ }^{2}$ Elan group from Slovakia considers the risk, as is most often analyzed in artistic world, as a conflict in coexistence relation between men and women. For a man in love a danger of unfavorable future development of events results from insufficient knowledge of the previous state of the monitored person, and the consequent potential incorrect conclusions. ${ }^{3}$ In a similar way, the term risk occurs in the Czech songs. However a singer-songwriter and a lyricist, Jaromír Nohavica, also introduces a new indicator for measuring risk, the coefficient of risk, but the exact manner of its construction he has not elaborated yet. ${ }^{4}$ There are not too many poems dedicated to risk. One of the most interesting and even very often quoted is the poem "Risk" by W.A. Ward", where he points out that every human activity can lead to failure, and that a man is exposed at least to the risk of ridicule from other people. But the one who does nothing, who does not attempt, actually does not exist. So only the one who risks becomes truly free. ${ }^{6}$ In the visual arts the risk is usually displayed as

1 Marek, P.: Studijní průvodce financemi podniku. (In English: Study Guide for Corporate Finance). Praha, Ekopress, 2009, p. 75.

2 I'd rather stand on the edge of a cliff, and hang my toes over a bit. (Brandt, P.: Risk)

3 I found a super chick, she has doubtful past. (In Slovak: Našiel som si super kost', má pochybnú minulost'). (Elán: Risk)

4 Therefore, before going into action, add up height $a$, substance $b$ and pressure $c$, multiply by the risk coefficient, divide by weight of politics. (Nohavica, J.: The Dance between Eggs).

5 However, the authorship of this poem is disputed. Apart from William Arthur Ward (1921-1994) this poem is also attributed to Felice Leonardo Buscaglio (19241988), but mostly it is reported on the Internet that the author of the poem is not known.

6 To laugh is to risk appearing a fool, to weep is to risk appearing sentimental, to reach out to another is to risk involvement, to expose feelings is to risk exposing your true self, to place your ideas and dreams before a crowd is to risk their loss, to love is to 
a negative deviation from the expected result, as in the image "Estetikum of risks", by Romanian painter M. S. Oprea, where the figures appear with full of fear of the future. ${ }^{7}$ P. J. Mills, Canadian painter imagines the risk as an environmental damage which can ultimately lead to the extinction of the planet Earth, expressed in gradually blurring world map. ${ }^{8}$

At the end of my editorial, let me also try in my own verses to contribute to discussion on the artistic nature of the concept of risk.

The risk,

what is risk,

it is only small fly,

flying on the sky,

the risk is a dream,

bad or good dream,

which could be changed into life.

prof. Ing. Petr Marek, CSc.

Editorial board's chairman

European Financial and Accounting Journal

and investigator of the research plan

Development of Financial and Accounting Theory and its Application in Practice from Interdisciplinary Point of View

risk not being loved in return, to hope is to risk despair, to try is to risk to failure. But risks must be taken because the greatest hazard in life is to risk nothing. The person who risks nothing, does nothing, has nothing is nothing. He may avoid suffering and sorrow, but he cannot learn, feel, change, grow or live. Chained by his servitude he is a slave who has forfeited all freedom. Only a person who risks is free. (Ward, W. A.: Risk)

7 Painting Aesthetics of Risk by Mai Stefan Oprea. [on-line], High Point, FineArtAmerica, c2009, [cit.: $1^{\text {st }}$ August, 2011],

<http://fineartamerica.com/featured/the-aesthetics-of-risk-maia-oprea.html>.

8 Painting Risk by Patrick John Mills [on-line], Ottawa, Patrick John Mills Contemporary Fine Art Gallery, c2009, [cit.: $1^{\text {st }}$ August, 2011],

<http://www.patrickjohnmills.com/MapSeries.htm>. 